\title{
Variasi Presipitasi Pelarut pada Ekstraksi RNA dengan Metode Trizole dan Pengaruh terhadap Kemurnian RNA
}

\author{
Variations of Precipitation Solvents in Extraction of RNA by Trizole \\ Method and Effect on RNA Purity
}

\author{
Shaomianah, S1, Khoirunisak, A.R ${ }^{1}$, Imana, Z.N11, Hadi, S², \\ Sucipto, T. $\mathrm{H}^{3 *}$, Soegijanto, $\mathrm{S}^{3}$ \\ 1Undergraduate Student, Department of Chemistry, Faculty of Science and Technology, \\ Universitas Airlangga \\ ${ }^{2}$ Department of Chemistry, Faculty of Science and Technology, Universitas Airlangga \\ 3Dengue Study Group, Institute of Tropical Disease, Universitas Airlangga \\ *email: teguhharisucipto@staf.unair.ac.id
}

\begin{abstract}
ABSTRAK
Virus dengue ditularkan oleh nyamuk Aedes aegypti dan Aedes albopictus. Nyamuk-nyamuk tersebut endemik di sebagian besar daerah vektor-vektor itu muncul memiliki empat serotipe yang berbeda secara antigenik. Empat serotipe virus dengue: DENV-1, DENV-2, DENV-3 dan DENV-4. Penelitian ini bertujuan untuk mengetahui perbandingan pelarut yang baik terhadap virus Dengue RNA Surabaya tipe-1 (DENV-1). Pelarut yang digunakan adalah Isopropanol, dimethyl sulfoxide, $96 \%$ ethanol, methanol, acetone-Methanol (1: 1), dimethyl formamide, dan akuades. RNA diisolasi dengan metode TRIzol. TRIzol (atau TRI Reagent) adalah larutan satu fasa dari fenol dan guanidinium isothiocyanate yang secara bersamaan melarutkan bahan biologis dan mendenaturasi protein. Hasil dari penilitian ini adalah didapatkan pelarut presipitasi RNA terbaik adalah aseton-metanol (1:1), karena campuran pelarut tersebut memiliki konstanta dielektrik terendah. Studi ini menunjukkan bahwa pelarut aseton-metanol (1:1) dapat digunakan sebagai pelarut presipitasi untuk mengisolasi RNA
\end{abstract}

Kata kunci: DENV-1, metode TRIzol, pelarut presipitasi, konstanta dielektrik

\begin{abstract}
Dengue viruses are transmitted between humans by Aedes aegypti and Aedes albopictus mosquitoes. They are endemic in most areas in which the vectors occur has four antigenically distinct serotypes. Four serotypes of dengue virus: DENV-1, DENV-2, DENV-3 and DENV-4. This research aims to determine the ratio of good solvents to RNA isolation for Virus dengue type-1 (DENV-1) precipitation. The solvents were used isopropanol, dimethyl sulfoxide, Ethanol 96\%, methanol, acetone-methanol (1:1), dimethyl formamide, and distillate water. The RNA isolated with TRIzol method. TRIzol (or TRI Reagent) is monophasic solution of phenol and guanidinium isothiocyanate that simultaneously solubilizes biological material and denatures protein. The result of the research is the best solvent precipitation RNA is acetonemethanol (1:1), because it has the lowest dielectric constant. This study showed that acetonemethanol can used as precipitation solvent for isolating RNA
\end{abstract}


Keywords: DENV-1, TRIzol method, precipitation solvents, dielectric constant

\section{$\cos (\cos )$ \\ INTRODUCTION}

Dengue virus (family Flaviviridae, genus Flavivirus) has four antigenically distinct serotypes (Johnson et al., 2005). Infection with any of them generally leads to a mild, self-limiting febrile illness (dengue fever). However, a more severe form of the disease or Dengue Hemorrhagic Fever - Dengue Shock Syndrome (DHF - DSS) is responsible for a high mortality rate, primarily among children (Lanciotti et al., 1992). Four serotypes of dengue virus: DENV-1, DENV-2, DENV-3 and DENV-4 are transmitted by the vector mosquitoes such as Aedes aegypti and Aedes albopictus (Halstead, 2008). Dengue virus is transmitted through the bite of a female mosquito. Transmission can occur when Aedes female mosquitoes are sucking blood of people infected with dengue virus and the mosquito will soon bite others (Maharani et al., 2018). The main clinical manifestations, namely Dengue Hemorrhagic Fever (DHF) and Dengue Shock Syndrome (DSS) are responsible for high morbidity and mortality rates every year. Over $40 \%$ (2.5 billion) of the population in 100 tropical and subtropical countries continue to live under of contracting dengue infection. It is estimated that 100 million cases of Dengue Fever (DF), 500,000 cases of DHF, and 25,000 deaths are reported annually worldwide. Indonesia is the one of the tropical countries that are affected by the Dengue Virus (DENV) (WHO, 2017). In dengue-endemic areas, dengue infections are recorded annually, with non-immune children being the principal susceptible hosts. In addition, epidemics occur when a vector is introduced into previously dengue-free areas (Gubler., 1988). The viruses replicate in cells of the macrophage-mononuclear cell lineage, and the severity of disease appears to be correlated with the ability of the viruses to 
infect cells. Infection with one of the serotypes stimulates the production of neutralizing antibodies directed against the envelope protein, conferring lifelong immunity to the serotype. The existence of waning neutralizing antibodies to one serotype may promote the enhancement of infection upon subsequent infection with another serotype. In this antibodydependent enhancement model, severe disease is postulated to be the result of heterologous, non-neutralizing antibodies facilitating virus infection of mononuclear cells. Alternatively, it has been postulated that there exist viral and/or other host factors which may be primary risk factors in the production of more disease (Lanciotti et al., 1992).

TRIzol (or TRI Reagent) is monophasic solution of phenol and guanidinium isothiocyanate that simultaneously solubilizes biological material and denatures protein (Rio et al., 2010). TRIzol extraction is a straightforward way to prepare RNA from cells or tissues. Although TRIzol removes large DNA molecules efficiently, it does not remove plasmid DNA or DNA fragments efficiently, which can be problematic for subsequent polymerase chain reaction (PCR) applications. However, when used appropriately, the RNA yield is quantitative (Rio et al., 2010). Ethanol precipitation is a commonly used technique for concentrating and de-salting nucleic acids (DNA or RNA) preparations in aqueous solution. The basic procedure is that salt and ethanol are added to the aqueous solution, which forces the precipitation of nucleic acid nucleic acids out of the solution. Combining guanidinium isothiocyanate and phenolchloroform extraction for RNA extraction has been reported (Chomczynski and Sacchi, 1987). The method describe differs in that it converts the guanidinium-hot phenol method to a single-step extraction which allows extraction of RNA in 4 hours and provides both high yield and purity of undegraded RNA preparations. The 
process of extraction RNA was through

several stages and in that stage, the role of

solvent is very important that is to know

the level of effectiveness of the solvent used and its impact on the results of the extraction (Maharani et al., 2018).

In the present study, a new rapid procedure using Isopropanol, Dimethyl Sulfoxide (DMSO), Ethanol 96\%, Methanol, Acetone-Methanol, Dimethyl Formamide (DMF), and distilled water. Extraction for RNA using TRIzol to get a good quality of RNA is described.

MATERIALS AND METHODS

Material
This research used chemical reagent is Virus dengue Surabaya strains (dengue virus types 1 Genbank: AB915377), Isopropanol (Merck, Germany), Methanol (Merck, Germany), Chloroform (Merck, Germany), Ethanol 96\% (Merck, Germany), Acetone (Merck, Germany), DMF (Dimethyl Formamide) (Merck, Germany), DMSO (Dimethyl Sulfoxide) ((Merck, Germany), and distilled water. Material for Reverse Transcription by Invitrogen (Germany), Polymerase chain reaction reagent by Promega (USA) and Primer reverse using TS (Type specific): D1, TS1, TS2, TS3, TS4 (Sequences are mentioned in Table 1).

Table 1. Oligonucleotide primers for RT-PCR and PCR (Lanciotti et al. (1992)).

\begin{tabular}{|c|c|c|c|}
\hline Primer & Sequence & $\begin{array}{l}\text { Genome } \\
\text { Position }\end{array}$ & $\begin{array}{l}\text { Size, in bp, of } \\
\text { amplified } \\
\text { DNA } \\
\text { product } \\
\text { (primers) }\end{array}$ \\
\hline D1 & 5'-TCAATATGCTGAAACGCGCGAGAAACCG-3' & $134-161$ & 511 \\
\hline TS1 & 5'-CGTCTCAGTGATCCGGGGG-3' & $568-586$ & 482(D1 and TS1) \\
\hline
\end{tabular}

(C)2020. Shaomianah et al. Open access under CC BY - SA license, doi: $10.20473 / \mathrm{mkh} . v 31 i 1.2020 .33-44$ 


\begin{tabular}{llcl}
\hline TS2 & 5'CGCCACAAGGGCCATGAACAG-3' $^{\prime}$ & 232-252 & 119(D1 and TS2) \\
TS3 & 5'-TAACATCATCATCATGAGACAGAGC-3' $^{\prime}$ & $400-421$ & 290(D1 and TS3) \\
TS4 & 5'-CTCTGTTGTCTTAAACAAGAGA-3' $^{\prime}$ & $506-527$ & 392(D1 and TS4)
\end{tabular}

\section{METHODS}

\section{RNA extraction}

Extraction of RNA with TRIzol method. The reagent positive dengue virus type 1 was transferred to seven new tubes of $300 \mu \mathrm{l}$ each. Then each sample was added with $700 \mu \mathrm{l}$ of TRIzol reagent and shaken vigorously. Furthermore, the samples were incubated for 5 minutes at room temperature. Then the sample was added with chloroform as much as $0.2 \mathrm{ml}$ and matched again. The sample was incubated at 2-3 minutes at room temperature. The sample was then centrifuged $12.000 \mathrm{~g}$ for 15 minutes at $4^{\circ} \mathrm{C}$. After that, the colorless solution in the upper layer is transferred to the new tube. Then the seven samples were each added with different reagents, sequentially from the first tube namely isopropanol, DMSO, ethanol 96\%, methanol, acetone methanol
(1:1), DMF, and distillate water. The amount of each reagent added $200 \mu 1$. Then all the samples are shaken vigorously. Then the sample was incubated for 10 minutes at room temperature. The sample was then centrifuged $12.000 \mathrm{~g}$ for 10 minutes at $4^{\circ} \mathrm{C}$. Furthermore, the supernatant in the tubes is removed, and the pellet is left. Then the RNA pellet was washed with $75 \%$ ethanol as much as $1 \mathrm{ml}$. then each tube was shaken with vortex and centrifuged 7500 for 5 minutes at $4^{\circ} \mathrm{C}$. Then the RNA is dried for 5-10 minutes. After that, the RNA was dissolved into $30 \mu 1$ RNase Free $\mathrm{H}_{2} \mathrm{O}$ at a temperature of around $55-60^{\circ} \mathrm{C}$. Finally, the results of RNA isolation are stored at $-80^{\circ} \mathrm{C}$. RNA measurements were quantitatively performed using nanodrop spectrophotometry with a polysaccharides absorb most UV light at $\lambda 260 \mathrm{~nm}$ and 
protein at $\lambda 280 \mathrm{~nm}$.

\section{Reverse transcriptase-polymerase chain} reaction (RT-PCR)

RT-PCR step used primer set described by Lanciotti et al. (1992) and used concentration from the reagent isolation of RNA. In cDNA synthesis, there are two stages, namely Reverse Transcription (RT) 1 and Reverse Transcription (RT) 2. Step RT-1 is $5 \mu$ RNA the results of isolation added $9 \mu 1$ master mix at each sample. Which master mix was already contained NFW $7 \mu \mathrm{l}$, dNTP $1 \mu \mathrm{l}$, and primer RT PCR $1 \mu \mathrm{l}$. Then the mix was lowered quickly or spin down with mini centrifuge and was incubated 5 minutes at $65{ }^{\circ} \mathrm{C}$. Then continued with RT-2, the result of incubation was added with a $5.5 \mathrm{ml}$ master mix which already contained $4 \mu \mathrm{l} \mathrm{FS} \mathrm{buffer}$ 5X, DTT $1 \mu \mathrm{l}$, and SuperScripts $0.5 \mu \mathrm{l}$. then the mixture is shaken and incubated at 50 ${ }^{\circ} \mathrm{C}$ for 60 minutes and, $85{ }^{\circ} \mathrm{C}$ for 5 minutes.

\section{PCR (polymerase chain reaction)}

PCR reactions were used proceed in thermalcycler programmed $5 \mu \mathrm{l}$ of positive control and $5 \mu \mathrm{l}$ of the results of each sample from incubation was added with a PCR mix of $6.25 \mu l ; 0.5 \mu l$ to each reverse and forward primers; and 0,25 $\mu \mathrm{l}$ of NFW. Then the mixture was spin down. Next, the sample was setup in 35 cycles of denaturation $\left(94^{\circ} \mathrm{C}, 1 \mathrm{~min}\right)$, primer annealing $\left(55^{\circ} \mathrm{C}, 1 \mathrm{~min}\right)$, and primer extension $\left(72^{\circ} \mathrm{C}, 2 \mathrm{~min}\right)$.

\section{Electrophoresis}

The process of Electrophoresis was made electrophoresis gel agarose $1.5 \%$ in TAE Buffer 0.5X. Then the electrophoresis process was run with $100 \mathrm{~V}$ for 30 minutes. After that, the gel was stained with EtBr solution for 30 minutes. Finally, the gel is transferred to the ultraviolet transilluminator for visualization.

\section{RESULT AND DISCUSSION}

In this report, we have described solvent that we have used for precipitation of RNA. In this research, we have been able to complete the RT-PCR assay, starting 
from RNA isolation and completing with

agarose gel analysis. The DNA DENV-1

isolation results were demonstrated on

electrophoregram (Figure 1) almost all

variations with various solvent

modifications DNA bands give bad intensity, except for the DNA bands on line

5. DNA band of line $M$ was the result of marker. The negative control in line $\mathrm{N}$ and positive control in line P. Positive control was used the dengue virus serotype DENV-1 (482bp).

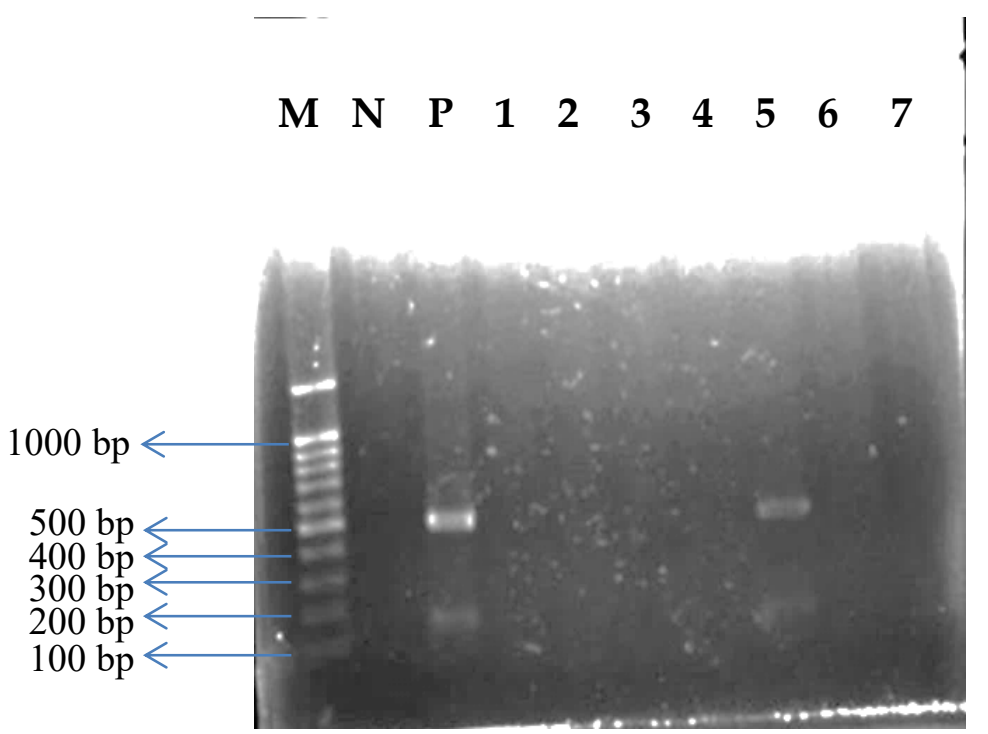

Figure 1. Electrophoregram of DNA DENV-1 from RNA extraction method from various solvents. Line (M) Marker $100 \mathrm{bp}$, (N) Negative Control, (P) Positive Control, (1) Isopropanol, (2) DMSO, (3) Ethanol 96\%, (4) Methanol, (5) Asetone Methanol (1:1), (6) DMF, (7) Distilled water.

Extraction RNA with TRIzol separation, where protein is extracted to method was done by TRIzol reagent. the organic phase, DNA resolves at the TRIzol (or TRI Reagent) is a monophasic interface, and RNA remains in the aqueous solution of phenol and guanidinium phase (Rio et al., 2010). The chloroform in isothiocyanate that simultaneously TRIzol is colored pink, making the three solubilizes biological material and layers easily distinguishable from each denatures protein. After solubilization, the other. The aqueous phase is transferred to addition of chloroform causes phase new tube where the RNA is extracted by (c)2020. Shaomianah et al. Open access under CC BY - SA license, doi: 10.20473/mkh.v31i1.2020.33-44 Received: 16-11-2019, Accepted: 07-01-2020, Published online: 29-01-2020 Available at https:/ / e-journal.unair.ac.id/MKH/index 
solvent precipitation. The precipitation

solvent is used in this research are

isopropanol (line 1), DMSO (line 2), ethanol 96\% (line 3), methanol (line 4), aseton methanol (1:1) (line 5), DMF (line 6), distilled water (line 7). The process of precipitation with solvents before the pellet was dried can increase the degree of purity of isolated RNA (Maharani et al., 2018). Nucleic acids like DNA or RNA can interact electrostatically with the water molecules, allowing them to easily dissolve in water. Polar molecules can therefore be described as hydrophilic and non-polar molecules, which can't easily interact with water molecules, are hydrophobic. Nucleic acids are hydrophilic due to the negatively charged phosphate $\left(\mathrm{PO}_{4}^{3-}\right)$ groups along the sugar phosphate backbone (Oswald, 2007). In solution, guanidium isothiocyanate breaks up into cation guanidium $\left(\mathrm{NH}_{2}\right)_{2} \mathrm{C}=\mathrm{NH}_{2}{ }^{+}$ and anion isothiocyanate [SCN]- (Mason et al., 2003). The positively charged guanidium ions neutralize the negative charge on the $\mathrm{PO}_{4}^{3-}$ groups on the nucleic acids, making the molecule less hydrophilic, and therefore much less soluble in water. The electrostatic attraction between the $\left(\mathrm{NH}_{2}\right)_{2} \mathrm{C}=\mathrm{NH}_{2}{ }^{+}$ions in solution and the $\mathrm{PO}_{4}^{3-}$ ions are dictated by Coulomb's Law, which is affected by the dielectric constant of the solution. Water has a high dielectric constant, which makes it fairly difficult for the $\left(\mathrm{NH}_{2}\right)_{2} \mathrm{C}=\mathrm{NH}_{2}{ }^{+}$and $\mathrm{PO}_{4}{ }^{3-}$ to come together. Precipitation solvent for example: ethanol on the other hand has a lower dielectric constant, making it easier for $\left(\mathrm{NH}_{2}\right)_{2} \mathrm{C}=\mathrm{NH}_{2}{ }^{+}$to interact with the $\mathrm{PO}_{4}{ }^{3-}$, shield its charge and make the nucleic acid less hydrophilic, causing it to drop out of solution. So, ethanol was the most important solvent option used in the RNA isolation process. Based on the principle of the precipitation solvent, other solvents than ethanol can be used as in previous research using isopropanol, methanol (Untoro et al., 2018), DMSO, ethanol 96\%, and acetone (Maharani et al., 2018). They 
are including in polar solvents and have almost the same solubility properties as ethanol. Some important properties of solvents include ability to solubility, the velocity evaporates, boiling route, specific gravity, flashpoint. This equation was allowed them to be used as a replacement solvent when ethanol was absent. The dielectric constant of the solution used in this research showed in Table 2.

Tabel 2. Dielectric constant of solvents at $25^{\circ} \mathrm{C}$ (Martin, 2006).

\begin{tabular}{ll}
\hline Name of solvent & Dielectric constant $(\boldsymbol{\varepsilon})$ \\
\hline Water & 78.5 \\
Isopropanol & 18.3 \\
Ethanol & 24.3 \\
Methanol & 32.6 \\
Asetone & 20.7 \\
DMSO & 47 \\
DMF & 38 \\
\hline
\end{tabular}

For the dielectric constant the mixture of acetone methanol (1:1) solvent is determined using the following formula: $\frac{\varepsilon \text { acetone }+\varepsilon \text { methanol }}{2}$ and the dielectric constant is obtained 26.65 as the acetone methanol solvent has the lowest dielectric constant value after isopropanol and ethanol $96 \%$ so that it has the potential to extract RNA better. After several incubation and centrifugation steps, the resulting pellet of purified RNA is washed in $75 \%$ ethanol solution, air-dried, and resuspended in an aqueous buffer such as RNAse-Free Water.

The next step is to know RNA measurements were quantitatively performed using nanodrop spectrophotometry with an absorbance 
ratio of 260/280 $\mathrm{nm}$. Absorbance data RNA capable of absorbing ultraviolet light showed in Table 3. The principle of due to the presence of purine pyrimidine nanodrop spectrophotometric work pure bases (Fatchiyah., 2011).

Table 3. The data result of Nanodrop Spectrophotometry for RNA sample

\begin{tabular}{lc}
\hline \multicolumn{1}{c}{ Sample } & A260/280 nm \\
DENV1 - Isopropanol & 1.78 \\
DENV1 - DMSO & 1.36 \\
DENV1 - Ethanol 96\% & 1.54 \\
DENV1 - Methanol & 1.01 \\
DENV1 - Asetone Methanol (1:1) & 1.81 \\
DENV1 - DMF & 1.70 \\
DENV1 - Distilled Water & 1.40 \\
\hline
\end{tabular}

The presence of contaminants can also be known through spectrophotometer. Protein were absorbed most UV light at $\lambda 280 \mathrm{~nm}$. The level of purity of RNA can be known by measuring the amount of sample absorbance at $\lambda 260 \mathrm{~nm}$ and $\lambda 280 \mathrm{~nm}$ then measuring large comparison (ratio) A260 to A280. Pure RNA isolate has an A260/ A280 ratio of 1.8 - 2.1 (Farrel., 2005). A low A260/A280 ratio indicates protein contamination. From the test results can be known that at A260/280 nm many samples have a ratio of less than 1.8, excepted acetone metanol (1:1). It can be stated that the other RNA isolate is contaminated with proteins. In the above data can be seen nanodrop results for acetone methanol on A260/280 nm higher than the other five solvents. Protein contamination can occur because during the extraction process using chloroform solvent, proteins do not separate completely into the organic phase. Because 
University (Ethics Committee Approval

Number: 24-934/UN3.14/PPd/2013).

appeared only on line 5 .

\section{CONCLUSION}

The conclusion is modification of RNA isolation methods from DENV-1 expected to produce a good quality RNA. Good RNA quality can be seen with the high intensity of the resulting DNA band and the low intensity of the smear. Thus, from this study reported that asetone methanol (1:1) precipitation solvent give the best results precipitation solvent.

\section{ACKNOWLEDGMENTS}

We thank to the Center of

Excellence (COE) program by the Ministry of Research, Technology, and Higher Education of the Republic of Indonesia.

\section{APPROVAL OF ETHICAL}

\section{COMMISION}

This study was approved by the Ethics Committees of Airlangga

\section{REFERENCES}

Chomczynski, P. and N. Sacchi .1987. Single-step Method of RNA Isolation by Acid Guanidinium ThiocyanatePhenol-Chloroform Extraction. Anal. Biochem; 162(1): 156-159.

Farrell, R.E. 2005. RNA methodologies: A Laboratory Guide for Isolation and Characterization. $3^{\text {rd }}$ ed. Elsevier Academic Press, Burlington

Fatchiyah A, E.L. Arumingtyas., S. Widyarti., S.Rahayu .2011. Biologi Molekular Prinsip Dasar Analisis. Malang: Erlangga.

Gubler, D.J. 1988.Dengue, p. 223-260. In T. P. Monath (ed.), The arboviruses: epidemiology and ecology, vol. 2. CRC Press, Boca Raton, Fla

Halstead, S.B. 2008. Dengue VirusMosquito Interactions. Annu Rev Entomol; 5: 273-91.

Johnson, B.W., B.J. Russell., R.S. Lanciotti. 2005. Serotype-Specific Detection of 
Dengue Viruses in a Fourplex Real-

Time Reverse Transcriptase PCR

Assay, J. Clin Microbiol; 43(10): 49774983

Lanciotti, R.S., C.H. Calisher., D.J. Gubler., G.J. Chang., and A.V. Vorndam .1992. Rapid detection and typing of dengue viruses from clinical samples by using reverse transcriptase polymerase chain reaction, J. Clin Microbiol; 30(3): 545-551

Maharani, A., T.H. Sucipto., H. Setyawati., S. Churrotin., I.H. Amarullah., P. Wardhani., A. Aryati., S. Ueda., and S. Soegijanto .2018. RNA Isolation of Dengue Virus Type 1 with Different Precipitation Solvents: Dimethyl Sulfoxide, Acetone, and Ethanol 70\%. Indo. J Trop Infect Dis; 7(3): 62-66

Mason, P.E., G.W. Neilson., C.E. Dempsey., A.C. Barnes., and J.M. Cruickshank .2003. The hydration structure of Guanidinium and Thiocyanate ions: Implications for protein stability in aqueous solution. Proceedings of the
National Academy of Sciences of the United States of America; 100(8): $4557-4561$

Rio, Rio, D.C., M. Ares Jr., G.J. Hannon., and T.W. Nilsen .2010. Purification of RNA using TRIzol (TRI Reagent). Cold Spring Harb Protoc; 5(6): 20102013

Untoro, Y.M., T.H. Sucipto., H.Setyawati., S.Churrotin., I.H. Amarullah., P. Wardhani., A. Aryati., S. Ueda., and S. Soegijanto .2018. RNA Isolation of Dengue Virus Type 2 with Different Precipitation Solvents: Methanol, Chloroform, and 2-Isopropanol. Jurnal Kimia Riset; 3(1): 52-57 WHO. 2017. Epidemiology Unit, Ministry of Health: Dengue update, 16 2017. https:/ / reliefweb.int/report/srilanka/epidemiology-unit-ministryhealth-dengue-update-16-november2017 